\title{
Neuroprotective effect of the recombinant human leukemia inhibitory factor in mice with an experimental cuprizone model of multiple sclerosis: possible mechanisms
}

\author{
I. F. Labunets ${ }^{1}$, A. E. Rodnichenko ${ }^{1}$, N. O. Melnyk ${ }^{1}$, S. E. Rymar ${ }^{1,2}$, \\ N. A. Utko ${ }^{1}$, G. O. Gavrulyk-Skyba ${ }^{1}$, G. M. Butenko ${ }^{1}$ \\ ${ }^{1}$ Institute of Genetic and Regenerative Medicine, NAMS of Ukraine \\ 67, Vyshgorodska Str., Kyiv, Ukraine, 04114 \\ 2 Institute of Molecular Biology and Genetics, NAS of Ukraine \\ 150, Akademika Zabolotnoho Str., Kyiv, Ukraine, 03680 \\ irina_labunets@ukr.net
}

\begin{abstract}
Aim. To investigate the effects of the rhLIF recombinant human leukemia inhibitory factor on the structural and functional changes in the central nervous system in the cuprizone-induced experimental model of multiple sclerosis in mice and to evaluate the involvement of the brain macrophages, T-lymphocytes and antioxidant enzymes in the observed rhLIF effects. Methods. Young $129 / \mathrm{Sv}$ mice were fed with the cuprizone neurotoxin daily for three weeks. rhLIF was injected daily $(50 \mu \mathrm{g} / \mathrm{kg})$ after seven days of the cuprizone treatment. We used histology, flow cytometry, spectrophotometric and functional methods. Results. The cuprizone treatment resulted in an increase in the number of the brain and spinal cord neurons with destructive changes, the brain macrophages, $\mathrm{CD}^{+}$-cells and the content of malondialdehyde; it changes the behavior of animals, decreases the brain superoxide dismutase and glutathione peroxidase activities. The rhLIF injection partially or completely restored the cuprizone-changed parameters. The effect of rhLIF was preserved during two months after the experiment completion. Conclusions. The neuroprotective effect of rhLIF is connected with a decrease in the cuprizone-induced changes in the number of the brain T-cells and macrophages and the activity of antioxidant enzymes.
\end{abstract}

Ke y w o r d s: cuprizone, LIF, neuron, T-lymphocytes, macrophages, antioxidant enzymes

\section{Introduction}

Multiple sclerosis is one of the most widespread demyelinating pathologies of the central nervous system (CNS) with the damages of both neuron pericarion and myelin of nerve fiber accompa- nied by the development of motor, emotional, vegetative and cognitive impairments $[1,2]$. Recently, new approaches to the treatment of multiple sclerosis have been developed. One of such promising approaches is the activation of own neural stem cells (NSCs)/progenitors in

(C) 2018 I. F. Labunets et al.; Published by the Institute of Molecular Biology and Genetics, NAS of Ukraine on behalf of Biopolymers and Cell. This is an Open Access article distributed under the terms of the Creative Commons Attribution License (http://creativecommons.org/licenses/by/4.0/), which permits unrestricted reuse, distribution, and reproduction in any medium, provided the original work is properly cited 
CNS [3]. Activation of own NSCs can be influenced by various cellular factors, in particular, cytokines. The leukemia inhibitory factor (LIF) is a polyfunctional cytokine of the interleukin 6 (IL6) family playing an important role in the nervous system development and its post-injury recovery [4-10].

In neurodegenerative diseases, including multiple sclerosis, the important links in the mechanism of nerve cell damage are the activation of microglia/macrophages and T-lymphocytes, as well as the oxidative stress accompanying neuroinflammation [11, 12]. It has been established that during first hours/days after damage of the nervous system, LIF participates in the initiation of a neuroinflammatory reaction, in particular, attracting macrophages into the inflammatory area [13]. In this case, the expression of mRNA LIF in the glial cells of the nervous system increases [14]. LIF reveals also anti-inflammatory effects [15].

Studies on the possible ways of neuroprotective influence of recombinant human LIF (rhLIF) require adequate experimental models of demyelinating CNS pathologies. As such, the toxic model of multiple sclerosis, induced by cuprizone, is widely used. We as well as other investigators observed a damage of the oligodendrocytes and neurons, neuroinflammation, oxidative stress and a reduced activity of the antioxidant enzymes in CNS of animals with the experimental cuprizone-induced multiple sclerosis [11, 14, 16-18].

The aim of our work was to investigate the effects of rhLIF on the structural and functional changes in CNS in the cuprizone-induced experimental model of multiple sclerosis in mice and to evaluate the involvement of the brain macrophages, T-lymphocytes and antioxidant enzymes in the realization of LIF effects.

\section{Materials and Methods}

\section{Animals}

Experiments were conducted on young (3-5 months) female 129/Sv "wild type" (H-2b) mice $(n=42)$ from vivarium of the Institute of Genetic and Regenerative Medicine NAMS of Ukraine (IGRM). Mice were kept in standard vivarium conditions with a fixed light regimen 12:12. Biological tissues for studies were taken from animals at 9:00 a.m. by ether anesthesia. All experiments were carried out according to "European Convention for the Protection of Vertebrate Animals used for experimental and other scientific purposes" (Strasburg, 1986) (from 21.02.2006).

Cuprizone-induced demyelination. Mice were given cuprizone [bis(cyclohexylidenehydrazide)] («Sigma», USA), in an amount of $0.2 \%$ by weight, mixed with food, daily for 3 weeks [17].

Recombinant human LIF (rhLIF). LIF was cloned with RT-PCR technology using human placenta RNA as a template and was expressed in E.coli. The biological activity was checked on the mouse myeloid leukemia cell line M1 [19]. Cytokine was injected intraperitonealy daily, $50 \mu \mathrm{g} / \mathrm{kg}$ of body weight [20], after 7 days of receiving cuprizone (14 injections) [21]. The control group of mice fed with cuprizone received injections of phosphate buffered saline (PBS) according to a similar scheme.

Experimental groups: 1 - mice were kept on standard diet without cuprizone (untreated mice); 2 - mice receiving cuprizone-containing food for 3 weeks and PBS injections (control group); 3 - mice receiving both cupri- 
zone-containg food and rhLIF injections. Each group included 14 mice. Experiments were conducted after completion of cuprizone treatment on 7,21 and 60 days.

For morphological studies of the CNS structures (cortex, cerebellum and lumbar spinal cord) the histological sections were stained with toluidine blue (by Nissl) $[17,22]$. The number of unchanged neurons and neurons with moderate and severe structural changes were determined by morphometric analysis.

Behavioral responses of mice were studied using «open field» test $[22,23]$. The number of squares crossed (horizontal locomotor activity) and faecal boluses (emotional activity) and looks into minks (search activity) were recorded for $3 \mathrm{~min}$.

Malondialdehyde (MDA) content in brain tissues was determined according to Uchiyama [24].

Activities of antioxidant enzymes were assessed in supernatants of the brain homogenates (cerebellum, forebrain) using $\mu$ Quant Bio-Tek spectrophotometer (USA) [25].

Functional activity of brain macrophages. The brain microglial cells/macrophages and blood-derived macrophages have similar parameters, for example, the possibility to phagocytosis of latex beads [26-28]. Brain suspension of adherent cells was cultivated with latex beads for $45 \mathrm{~min}$ at $37^{\circ} \mathrm{C}$ in $5 \% \mathrm{CO}_{2}$. Then these cells were fixed and stained with Romanovsky-Gimsa. The percentage of brain macrophages capable of phagocytosis of latex beads (phagocytic index) and the amount of latex beads, which were phagocytosed by one macrophage (phagocytic number) were counted under light microscope. All reagents were supplied from Sigma (USA).
Flow cytometric analysis of $\mathrm{CD}^{+}$and $C D 11 b^{+}$-cells. The cells suspension of the brain tissue was incubated with monoclonal antibodies for $20 \mathrm{~min}$ at $4^{\circ} \mathrm{C}$ in combination with the saturating amounts of phycoerythrin (PE)-conjugated antibodies against CD3 (dilution 1:50) and fluorescein isothiocyanate (FITC)-conjugated antibodies against $\mathrm{CD} 11 \mathrm{~b}$ (dilution 1:50), as recommended by the manufacturer (Becton Dickinson, USA). Measurements were performed on the flow cytometer BD FACSAria (Becton Dickinson, USA), and the data analysis was performed using the BD FACS Diva 6.1 software.

Statistical analysis of the results was carried out using the Student's t-criterion [29]. The differences between the means of comparable groups $(\mathrm{M} \pm \mathrm{SEM})$ were significant at $\mathrm{p}<0.05$.

\section{Results}

Changes in the structure of neurons and brain macrophages activity in mice during early period of cuprizone treatment. One of the early manifestations of the development of cuprizone-induced multiple sclerosis is a change in the oligodendrocyte functioning and apoptosis development [14]. However, the neuronal structural changes in such animals are poorly studied. Histological analysis of brain structures has shown that a proportion of neurons with moderate structural changes increased in the cortex and cerebellum of mice after 7 days of the cuprizone treatment (Fig. 1, $A, B$ ). These results are in agreement with our earlier data: the horizontal locomotor activity revealed a significant decrease $(1.8$-fold, $\mathrm{p}<0.05)$ in the young $129 / \mathrm{Sv}$ mice after 7 days of the cuprizone treatment comparing to the untreated mice [21]. Apart from the changes in brain neurons of the cuprizone- 
treated mice, the number and the activity of brain macrophages increased if compared to the similar parameters in the group without cuprizone treatment (Fig. 2, $A, B$ ).

Influence of rhLIF injections on structural and functional changes in the CNS of mice treated with cuprizone during three weeks. After 7 days of the cuprizone treatment, rhLIF in the concentration of $50 \mu \mathrm{g} / \mathrm{kg}$ of body weight was injected. The control group of animals continued to receive only cuprizone. Comparison of the results of morphometric analysis of CNS structures of above groups showed a lower proportion of unchanged neurons and a greater share of the neurons with destructive changes in the control group, whereas in the experimental group the directions of these changes were opposite (Fig. 3, A,
$B, C)$. Thus, the rhLIF injections to cuprizonetreated mice resulted in the restorative and compensatory neuronal responses to a damage.

The behavioral reactions were significantly worsened in the cuprizone-treated mice (see Fig. 4, $A, B, C$ ). Injections of rhLIF led to an increase of the locomotor and search activity in comparison with similar parameters in the control group, although they remained lower than in untreated mice (Fig. 4, A, C). After injection of cytokine we observed an increase in the emotional activity to the level observed in the untreated group (Fig. 4, B).

Influence of rhLIF injections on brain macrophages, $T$ cells and antioxidant enzymes activity in mice treated with cuprizone during three weeks. The number of active macrophages in the brain of mice after 3 weeks

B

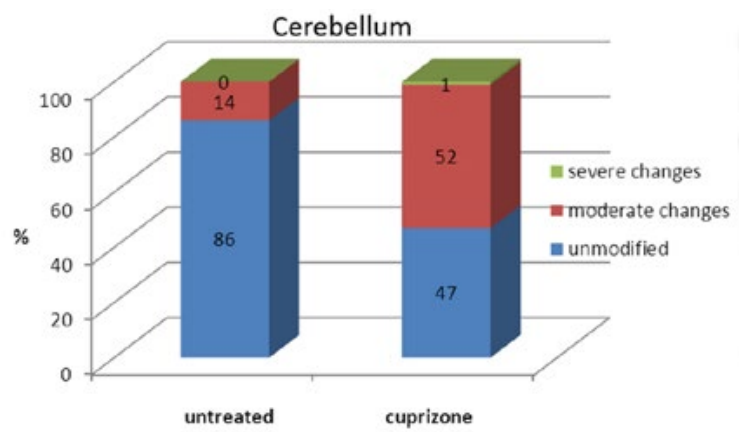

$\boldsymbol{A}$

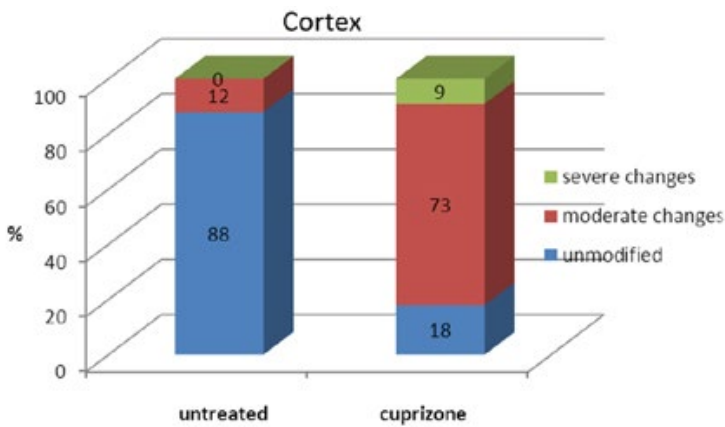

Fig. 1. Structural changes of brain neurons $(A-$ cortex, $B-$ cerebellum $)$ in mice after 7 days of cuprizone treatment.

$A$

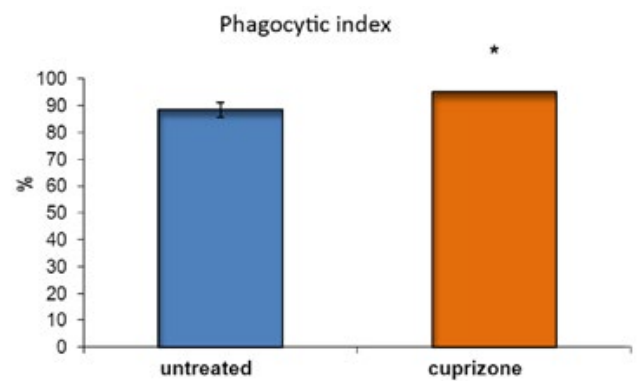

B

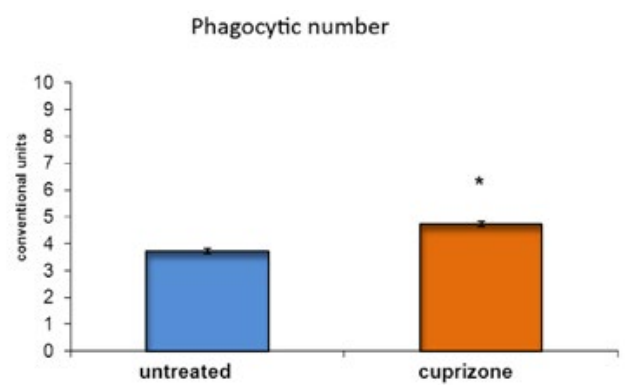

Fig. 2. Macrophages activity $(A-$ phagocytic index, $B$ - phagocytic number) in mice after 7 days of cuprizone treatment. $\mathrm{p}<0.05$ vs untreated mice. 
$\boldsymbol{A}$

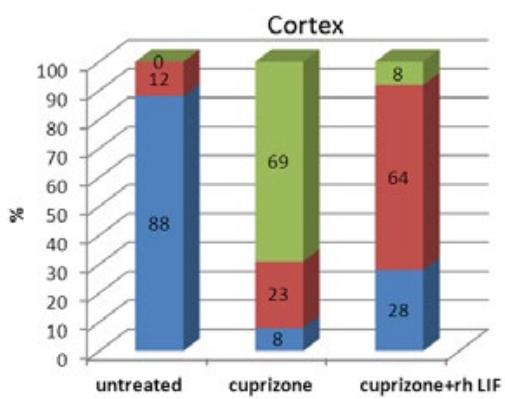

$\boldsymbol{B}$

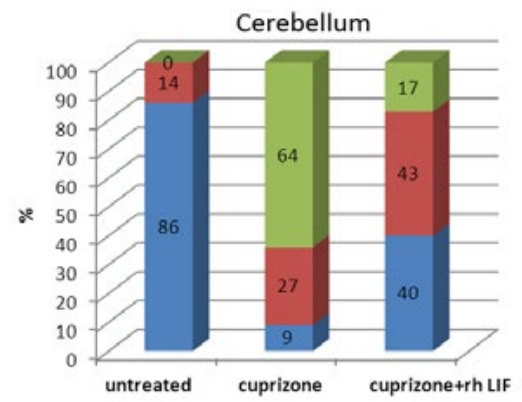

C

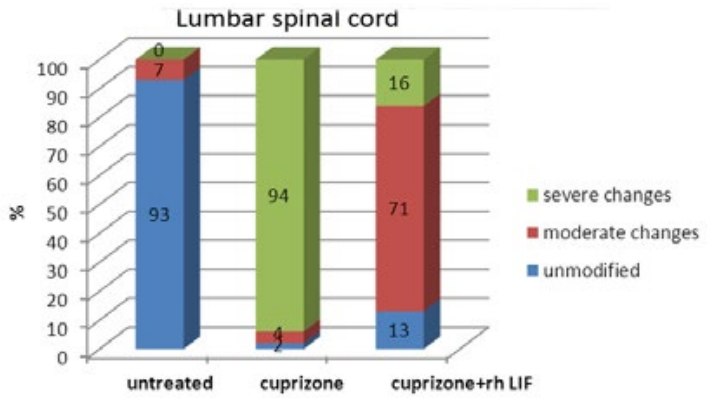

Fig. 3. The influence of cuprizone and rhLIF on the structural changes of CNS neurons $(A-$ cortex, $B-$ cerebellum, $C$ - lumbar spinal cord) in mice.

of the cuprizone treatment was higher than in the untreated animals and the rhLIF injections in such mice did not affect this parameter (Fig. 5, $A, B$ ). The number of CD11b ${ }^{+}\left(\mathrm{Mac1}^{+}\right)$ cells in the brain of cuprizone-treated mice $(2.8 \pm 0.2 \%)$ did not change in comparison with the untreated group $(2.8 \pm 0.1 \%)$, but after cytokine injections this number decreased to $1.8 \pm 0.2 \%(\mathrm{p}<0.05)$.

The number of $\mathrm{CD}^{+}$cells in the brain of mice significantly increased after the cuprizone
$\boldsymbol{A}$

Horizontal locomotor activity

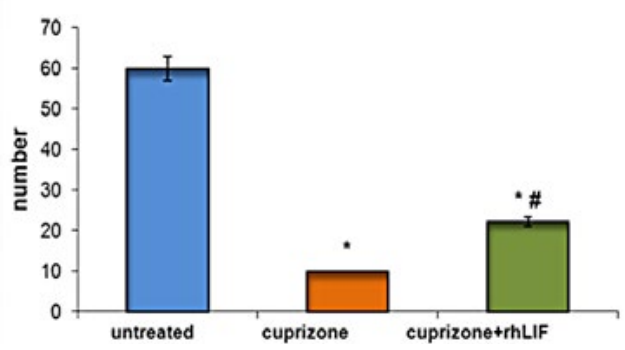

$\boldsymbol{B}$

Emotional activity

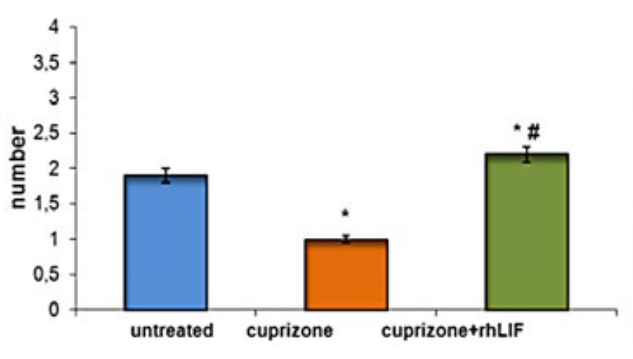

C

Search activity

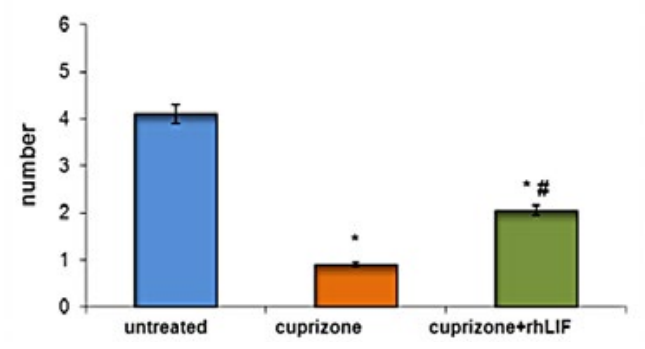

Fig. 4. The influence of cuprizone and rhLIF on the behavioural reactions ( $A-$ horizontal locomotor activity, $B$ - emotional activity, $C$ - search activity) in mice. $\mathrm{p}<0.05$ : * — vs untreated mice; \# — vs cuprizone. $\mathrm{Cu}$ prizone treatment lasted 3 weeks.

treatment (Fig. 5, C). However, the number of $\mathrm{CD}^{+}$cells decreased following the rhLIF injections, remaining still higher than in the untreated mice (Fig. 5, C).

Under the cuprizone influence one of the indices of oxidative stress (MDA content) significantly increased in the forebrain whereas the administration of rhLIF reduced the MDA content to the level of untreated 
$A$

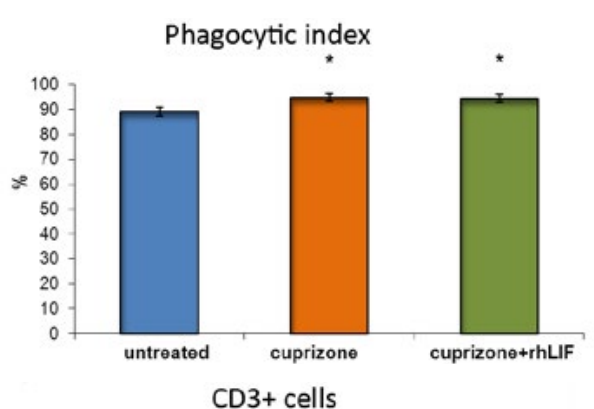

$C$

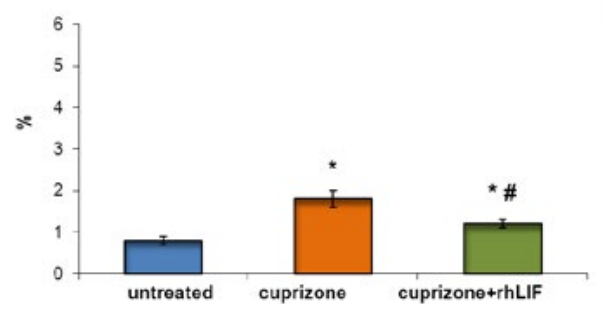

mice (Table). The superoxide dismutase (SOD) activity was significantly reduced in the forebrain of mice receiving cuprizone whereas the rhLIF injections restored this activity to the level of untreated animals (Table).

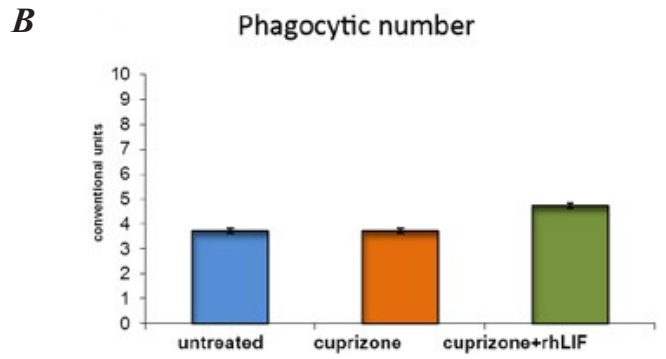

Fig. 5. The parameters of the macrophages activity ( $A-$ phagocytic index, $B$ - phagocytic number) and the number of $\mathrm{CD} 3+$ cells $(\mathrm{C})$ in the brain of cuprizone - and rhLIF — treated mice. $\mathrm{p}<0.05:{ }^{*}$ — vs untreated mice; \# - vs cuprizone. Cuprizone treatment lasted 3 weeks.

The activation of glutathione peroxidase (GPx) was observed in the forebrain of the mice receiving both cuprizone and cytokine (Table). After the cuprizone treatment the GPx activity in the cerebellum was significantly reduced whereas the rhLIF injections

Table. Malondialdehyde content and the activity of antioxidant enzymes in the brain structures of mice receiving cuprizone and $\mathrm{rhLIF}, \mathrm{M} \pm \mathrm{m}$

\begin{tabular}{|l|c|c|c|}
\hline \multirow{2}{*}{ Indice } & \multicolumn{3}{|c|}{ Experimental group of mice } \\
\cline { 2 - 4 } & Untreated & Cuprizone & Cuprizone +rhLIF \\
\hline Malondialdehyde $(\mathrm{nmol} / \mathrm{mg})$ & $1.50 \pm 0.10$ & $2.10 \pm 0.20^{*}$ & $1.60 \pm 0.10^{\#}$ \\
Superoxide dismutase $(\mathrm{U} / \mathrm{mg} \cdot \mathrm{min})$ & $12.75 \pm 0.35$ & $11.50 \pm 0.28^{*}$ & $12.0 \pm 0.53$ \\
Catalase $(\mu \mathrm{mol} / \mathrm{mg} \cdot \mathrm{min})$ & $1.28 \pm 0.12$ & $1.25 \pm 0.09$ & $1.59 \pm 0.26$ \\
Glutathione peroxidase $(\mathrm{nmol} / \mathrm{mg} \cdot \mathrm{min})$ & $5.23 \pm 0.21$ & $5.72 \pm 0.94$ & $6.56 \pm 0.32^{*}$ \\
\hline \multicolumn{3}{|c|}{} \\
\hline Malondialdehyde $(\mathrm{nmol} / \mathrm{mg})$ & Cerebellum & $1.60 \pm 0.10^{\&}$ & $1.70 \pm 0.20$ \\
Superoxide dismutase $(\mathrm{U} / \mathrm{mg} \cdot \mathrm{min})$ & $1.40 \pm 0.10$ & $12.75 \pm 0.14^{\&}$ & $13.50 \pm 0.35^{\&}$ \\
Catalase $(\mu \mathrm{mol} / \mathrm{mg} \cdot \mathrm{min})$ & $12.90 \pm 0.35$ & $1.29 \pm 0.07$ & $1.40 \pm 0.17$ \\
Glutathione peroxidase $(\mathrm{nmol} / \mathrm{mg} \cdot \mathrm{min})$ & $1.44 \pm 0.05$ & $7.50 \pm 0.11^{*}$ & $8.53 \pm 0.19^{\#}$ \\
\hline
\end{tabular}

Note: $\mathrm{p}<0.05: *$ _ vs untreated mice; \# — vs cuprizone (3-week treatment); \& — vs forebrain. Data of antioxidant enzyme activity in the cerebellum were shown earlier [30]. 
restored it to the level of untreated animals (Table).

Thus, the cuprizone-induced brain damage led to an increase in the number of macrophages and T-lymphocytes and inhibited the activity of antioxidant enzymes (SOD, GPx) in the mouse brain structures. This neurotoxin effect was significantly lower in the case of co-administration of cuprizone and rhLIF.

The long-term effects of rhLIF injections on cuprizone-induced changes in the neuronal structure and T-lymphocyte number in the mouse brain. Histological analysis of the mouse brain structures two months after completion of the cuprizone treatment showed that the number of unchanged neurons, neurons with moderate changes and neurons with pronounced structural changes was respectively: $13 \%, 69 \%$ and $28 \%$ in the cortex; and $35 \%, 43 \%$ and $22 \%$ in the cerebellum. The number of neurons with pronounced structural changes was lower and the number of unchanged neurons was higher in the cerebral cortex and cerebellum compared to the animals after 3 weeks of the neurotoxin treatment (Fig. 2, $A, B$ ). This fact can be explained by the reduction of neuroinflammation, which leads to an increase in the number of oligodendrocytes and remyelination [14]. In our study, two months after completion of administration of rhLIF and cuprizone the number of neurons without changes, with moderate and pronounced structural changes was $26 \%, 62 \%$, $12 \%$ in cerebral cortex; and $65 \%, 27 \%, 8 \%$ in the cerebellum, respectively. Importantly, the number of neurons of different types in the cerebellum two months after completion of the cuprizone treatment was comparable with their number after 3 weeks of the combined treatment with neurotoxin and rhLIF. Thus, the results indicate a more effective restoration of the neuronal structure following the cytokine injections.

Two months after completion of the cuprizone treatment the horizontal locomotor activity (the number of crossed squares) was lower in the cuprizone-treated mice comparing to the mice receiving both cuprizone and rhLIF: $11.0 \pm 1.5$ and $25.0 \pm 2.3,(\mathrm{p}<0.05)$, respectively. In both experimental groups, the indices remained lower $(\mathrm{p}<0.05)$ compared to the untreated group (Fig 4, A).

Two months after completion of the cuprizone treatment the number of the brain $\mathrm{CD}^{+}{ }^{+}$ cells $(1.2 \pm 0.1 \%)$ was lower than just after completion of the 3-week neurotoxin treatment $(p<0.05)$, whereas this parameter was still higher than in the untreated mice $(p<0.05)$ (Fig. 5, C). However, two months after completion of the combined administration of cuprizone and rhLIF the number of $\mathrm{CD}^{+}$cells $(1.0 \pm 0.1 \%)$ did not change noticeably comparing to the untreated mice $(\mathrm{p}>0.05)$ (Fig. 5, C).

So, the effects of rhLIF on the above changes induced by the cuprizone treatment remained the same for a long period of time.

\section{Discussion}

The myelin-synthesizing cells (oligodendrocytes) underwent apoptosis in the cuprizoneinduced model of multiple sclerosis [14]. Using the cuprizone-induced model of multiple sclerosis in mice, we observed a significantly increased number of the neurons with destructive changes in the cortex and the cerebellum of the brain and in the lumbar spinal cord. Damage of the neuron structure is accompanied with destruction of the locomotor, emotional and search activities. Our results agree with the findings of Ganong [31]. Apparently, 
the disorders of behavioral reactions induced by cuprizone result from both, the developing demyelination of CNS organs and the damage of brain and spinal cord neurons.

In our study of the cuprizone-treated mice the exogenous rhLIF improved the structure and functioning of CNS neurons. These morpho-functional changes can be explained by the literature data about the antiapoptotic action of LIF and its stimulating effects on the proliferation of NSCs in the brain subventricular zone and their differentiation into the neuronal direction, the formation of the oligodendrocytes and myelin synthesis [8-10,14].

Today, it is supposed that the activation of microglia cells and T-lymphocytes is one of the possible mechanisms of cuprizone-induced damage of the neurons. In particular, it has been shown that microgliosis develops on the $2^{\text {nd }}$ week of cuprizone treatment and it peaks by the 4-th week, being combined with the intensive demyelination [11]. The activated microglia cells of the brain produce an increased quantity of the proinflammatory cytokines (TNF- $\alpha$ and $\gamma$-interferon) and reactive oxygen species (ROS), which damage both, the oligodendrocytes and neurons [11,32]. We observed an increase of the number and activity of the macrophages after 7 days of the cuprizone treatment and this effect remained for 3 weeks.

The number of brain activated macrophages was large after the rhLIF injections. The proinflammatory phenotype M1 turns into the anti-inflammatory phenotype M2 in the process of the development of cuprizone-induced demyelination in the brain [11]. In our study the positive changes in the neuron structure allowed us to assume the realization of antiinflammatory effect by the macrophages fol- lowing cytokine treatment. Additionally, the number of $\mathrm{CD}_{11 b^{+}}\left(\mathrm{Macl}^{+}\right)$cells in the brain of mice reduces after administration of rhLIF. As has been shown, this phenotype is specific not only for macrophages but also for the microglia cells [26].

Some authors consider the cuprizone-induced model of multiple sclerosis as T-independent [12]. Kang et al. reported both infiltration of the brain by T-cells and their participation in the enhancing of the demyelination in the cuprizone-treated mice [33]. According to our results, we have observed an increase in the number of $\mathrm{CD}^{+} \mathrm{T}$ cells in the brain after 3 weeks of cuprizone diet as compared with the untreated mice (Fig. 5, C).

The number of $\mathrm{CD}^{+} \mathrm{T}$ cells in the brain after the rhLIF injections decreased compared with the mice without cytokine (Fig. 5, C). It is known that in human multiple sclerosis the T-cells and perivascular macrophages expressing LIF are seen in the area of damage [34]. In the athours' opinion, LIF prevents TNF- $\alpha$ - induced apoptosis of the oligodendrocytes that is an important mechanism for the protection of glial and neuronal cells. The similar results were received on the model of experimental autoimmune encephalomyelitis by Cao et al. [35]. Thus, the LIF, expressed by neural progenitor cells, inhibits the differentiation of T-helper 17 (Th 17) and production of proinflammatory cytokine IL-17. According to our preliminary data, we observed a decrease in the number of $\mathrm{CD}^{+}$-cells in the brain of cuprizone-treated mice.

After the cuprizone treatment we registered the reduced activity of antioxidant enzymes in the brain structures involved in the motor and emotional activity. This might be another possible mechanism of nerve cells damage caused 
by oxidative stress factors in cuprizone-treated mice $[16,18]$. We observed the enhancement of the activity of antioxidant enzymes in the brain along with the decrease of MDA content and the increase of the number of neurons without structural changes in the mice treated with both cuprizone and rhLIF. During CNS damage LIF inhibits the ROS generation and increases the SOD activity [36]. According to our data, LIF increases the activity of both SOD and GPx thereby contributing to the improvement of the structure of the CNS organs.

\section{Conclusion}

We observed the changes in the amount of the brain macrophages and $T$ cells as well as the balance disturbance in the pro- and antioxidant factors that could contribute to the cuprizoneinduced brain neuron damage. The above changes were detected already at early stages of the neurotoxin treatment. The neuroprotective effect of rhLIF is connected with the decrease of cuprizone-induced changes in the number of the brain T-cells and macrophages and an activity of the antioxidant enzymes. The effect of the cytokine remained during two months after completion of the cuprizone administration. The obtained results can serve as a basis for new approaches in cellular therapy for the patients with multiple sclerosis.

\section{Acknowledgments}

The study was carried out in the framework of "The role of the cell and endocrine factors in the realization of the neuroprotective properties of the stem cells in the experimental damages of the nervous system", being fulfilled by the IGRM, NAMSU (No of the state registration 0116U000139), 2016-2018.

\section{REFERENCES}

1. Wegner C, Esiri MM, Chance SA, Palace J, Matthews $P M$. Neocortical neuronal, synaptic, and glial loss in multiple sclerosis. Neurology. 2006;67(6):960-7.

2. Loma I, Heyman R. Multiple sclerosis: pathogenesis and treatment. Curr Neuropharmacol. 2011;9(3): 409-16.

3. Lindvall $O$, Kokaia Z. Stem cells in human neurodegenerative disorders--time for clinical translation? J Clin Invest. 2010;120(1):29-40.

4. Auernhammer CJ, Melmed S. Leukemia-inhibitory factor-neuroimmune modulator of endocrine function. Endocr Rev. 2000;21(3):313-45.

5. Bauer $S$, Patterson $P H$. Leukemia inhibitory factor promotes neural stem cell self-renewal in the adult brain. J Neurosci. 2006;26(46):12089-99.

6. Ostasov P, Houdek Z, Cendelin J, et al. Role of leukemia inhibitory factor in the nervous system and its pathology. Rev Neurosci. 2015;26(4): 443-59.

7. Nicola NA, Babon JJ. Leukemia inhibitory factor (LIF). Cytokine Growth Factor Rev. 2015;26(5):533-44.

8. Buono KD, Vadlamuri D, Gan Q, Levison $S W$. Leukemia inhibitory factor is essential for subventricular zone neural stem cell and progenitor homeostasis as revealed by a novel flow cytometric analysis. Dev Neurosci. 2012;34(5):449-62.

9. Li Y, Zang $D$. The neuron regrowth is associated with the proliferation of neural precursor cells after leukemia inhibitory factor administration following spinal cord injury in mice. PLoS One. 2014;9(12): e116031.

10. Deverman BE, Patterson PH. Exogenous leukemia inhibitory factor stimulates oligodendrocyte progenitor cell proliferation and enhances hippocampal remyelination. J Neurosci. 2012;32(6):2100-9.

11. Praet J, Guglielmetti C, Berneman Z, et al. Cellular and molecular neuropathology of the cuprizone mouse model: clinical relevance for multiple sclerosis. Neurosci Biobehav Rev. 2014;47:485-505.

12. González H, Pacheco R. T-cell-mediated regulation of neuroinflammation involved in neurodegenerative diseases. J Neuroinflammation. 2014;11:201. Review.

13. Sugiura S, Lahav R, Han J, Kou SY, Banner LR, de Pablo F, Patterson PH. Leukaemia inhibitory factor is required for normal inflammatory responses to injury in the peripheral and central nervous systems 
in vivo and is chemotactic for macrophages in vitro. Eur J Neurosci. 2000;12(2):457-66.

14. Gudi V, Gingele S, Skripuletz T, Stangel M. Glial response during cuprizone-induced de- and remyelination in the CNS: lessons learned. Front Cell Neurosci. 2014;8:73.

15. Banner LR, Patterson PH, Allchorne A, Poole S, Woolf $C J$. Leukemia inhibitory factor is an antiinflammatory and analgesic cytokine. $J$ Neurosci. 1998;18(14):5456-62.

16. Acs P, Selak MA, Komoly S, Kalman B. Distribution of oligodendrocyte loss and mitochondrial toxicity in the cuprizone-induced experimental demyelination model. J Neuroimmunol. 2013;262(1-2):128-31.

17. Labunets IF, Melnyk NO, Kuzminova IA, Butenko GM. Pat N 94458 UA (G09B 23. 28 (2006.01)), «Modeling of the structural changes of the central nervous system neurons in demyelinating diseases» $\mathrm{N}$ u 2014 06622; publ. 11.10.2014, Bull. N 21.

18. Xuan Y, Yan G, Wu R, Huang $Q, L i X, X u H$. The cuprizone-induced changes in (1)H-MRS metabolites and oxidative parameters in C57BL/6 mouse brain: Effects of quetiapine. Neurochem Int. 2015;90:185-92.

19. Rymar SE, Novikova SN, Irodov DM, Bazalii AV, Sukhorada EM, Kordum VA. Leukemia inhibitory factor: perspectives for use in medicine and development of its producer. $J$ NAMS Ukraine. 2010; 16:199-212.

20. Marriott MP, Emery B, Cate HS, Binder MD, Kemper D, Wu Q, Kolbe S, Gordon IR, Wang H, Egan G, Murray S, Butzkueven H, Kilpatrick TJ. Leukemia inhibitory factor signaling modulates both central nervous system demyelination and myelin repair. Glia. 2008;56(6):686-98.

21. Labunets IF, Melnyk NO, Rymar SYu. Pat N 104976 UA (G09B 23. 28 (2006.01)) «Modeling of regeneration of damaged brain neurons during neurodegenerative diseases", N u 2015 09252; publ. 02.25.2016, Bull N 4.

22. Labunets IF, Melnyk NO, Kuzminova IA, Pod'iachenko EV, Butenko GM. Effect of neurotoxin "cuprizone" on behavioral reactions and morphofunctional changes of cerebral and spinal cord neurons in mice. $J$ NAMS Ukraine. 2014; 20(4):402-8.
23. Amikishieva AV. Behavioral phenotyping: modern methods and equipment. Vestnik VOGiS. 2009; 13:529-42.

24. Mihara M, Uchiyama M. Determination of malonaldehyde precursor in tissues by thiobarbituric acid test. Anal Biochem. 1978;86(1):271-8.

25. Muradian KhK, Utko NA, Mozzhukhina TG, Pishel' IN, Litoshenko AIa, Bezrukov VV, Fraŭfel'd VE. [Correlative links between superoxide dismutase, catalase and glutathione peroxidase activities in mouse liver]. Ukr Biokhim Zh. (1999). 2003;75(1):33-7. Russian.

26. Guillemin GJ, Brew BJ. Microglia, macrophages, perivascular macrophages, and pericytes: a review of function and identification. $J$ Leukoc Biol. 2004;75(3):388-97.

27. Jordan FL, Wynder HJ, Booth PL, Thomas WE. Method for the identification of brain macrophages/ phagocytic cells in vitro. $J$ Neurosci Res. 1990;26(1):74-82.

28. Preclinical studies of drugs (guidelines). Ed. $O V$ Stephanov. Kiev: Avicenna, 2001. 528 p.

29. Lakin GF. Biometrics. Moscow: High School Publ. 1990, $350 \mathrm{p}$.

30. Labunets IF, Melnyk NO, Rodnichenko AE, Rymar SE, Utko NA. Cuprizone-Induced Disorders of Central Nervous System Neurons, Behavioral Reactions, Brain Activity of Macrophages and Antioxidant Enzymes in the Mice of Different Ages: Role of Leukemia Inhibitory Factor in their Improvement. $J$ Aging Geriatr Med. 2017; 1:2. 8 p.

31. Ganong V,F. Human physiology. Lviv: BaK, 2002. $784 \mathrm{p}$.

32. Lynch $M A$. Age-related neuroinflammatory changes negatively impact on neuronal function. Frontiers in Aging Neuroscience. 2010; 1, Article 6. - 8 p. Doi 10.3389. neuro.24.006.2009.

33. Kang Z, Liu L, Spangler R, Spear Ch, Wang Ch, Gulen MF, Veenstra M, Ouyang W, Ransohoff RM, $\mathrm{Li} X$. IL-17-induced Act1-mediated signalling is critical for cuprizone-induced demyelination. $J \mathrm{Neu}$ rosci. 2012; 32(4):8284-92.

34. Vanderlocht J, Hellings $N$, Hendriks JJ, et al. Leukemia inhibitory factor is produced by myelin-reactive $\mathrm{T}$ cells from multiple sclerosis patients and 
protects against tumor necrosis factor-alpha-induced oligodendrocyte apoptosis. J Neurosci Res. 2006;83(5):763-74.

35. Cao W, Yang Y, Wang Z, Liu A, et al. Leukemia inhibitory factor inhibits $T$ helper 17 cell differentiation and confers treatment effects of neural progenitor cell therapy in autoimmune disease. Iтmunity. 2011;35(2):273-84.

36. Chollangi S, Wang J, Martin A, Quinn J, Ash JD. Preconditioning-induced protection from oxidative injury is mediated by leukemia inhibitory factor receptor (LIFR) and its ligands in the retina. Neurobiol Dis. 2009;34(3):535-44.

\section{Нейропротекторний ефект рекомбінантного лейкемія-інгібіторного фактору людини у мишей з експериментальною купризоновою моделлю розсіяного склерозу: можливі механізми}

I. Ф. Лабунець, А. Є. Родніченко, Н. О. Мельник, С. Ю. Римар, Н. О. Утко, Г. О. Гаврилюк-Скиба, Г. М. Бутенко

Мета. Дослідити вплив рекомбінантного лейкемія інгібіторного фактору людини (rhLIF) на структурні та функціональні зміни ЦНС в експериментальній моделі розсіяного склерозу, індукованого у мишей купризоном; оцінити участь макрофагів, Т-лімфоцитів та антиоксидантних ферментів головного мозку в реалізації його проявів. Методи. Молоді миші лінії 129/Sv отримували нейротоксин купризон із їжею щодня протягом 3-х тижнів, rhLIF — з 8-ї доби прийому купризону щодня у дозі 50 мкг/кг. Методи: гістологічний, проточної цитометрії, спектрофотометричний і функціональний. Результати. Під впливом купризону в головному та спинному мозку мишей збільшується кількість нейронів $з$ деструктивними змінами; в головному мозку зростає кількість макрофагів, $\mathrm{CD}^{+}$-клітин і вміст малонового діальдегіду; знижується активність супероксидддисмутази, глютатіонпероксидази у головному мозку та змінюється поведінка тварин. Ін'єкції rhLIF частково або повністю відновлюють показники, змінені купризоном. Ефект цитокіна зберігається через 2 міс після завершення експерименту. Висновки. Нейропротекторний ефект rhLIF пов'язаний з пригніченням індукованих купризоном змін в активності антиокси- дантних ферментів, кількості Т-клітин і макрофагів у головному мозку

К л юч о в і с л о в а: купризон, LIF, нейрон, Т-лімфоцити, макрофаги, антиоксидантні ферменти.

\section{Нейропротекторный эффект рекомбинантного лейкемия-ингибирующего фактора человека у мышей с экспериментальной купризоновой моделью рассеянного склероза: возможные механизмы}

И. Ф. Лабунец, А. Е. Родниченко, Н. А. Мельник, С. Е. Рымарь, Н. А. Утко, Г. А. Гаврилюк-Скиба, Г. М. Бутенко

Цель. Исследовать влияние рекомбинантного лейкемия- ингибирующего фактора человека (rhLIF) на структурные и функциональные изменения ЦНС в экспериментальной модели рассеянного склероза, индуцированного у мышей купризоном; оценить участие макрофагов, Т-лимфоцитов и антиоксидантных ферментов головного мозга в реализации его проявлений. Методы. Молодые мыши линии 129/Sv получали нейротоксин купризон с пищей ежедневно в течение 3-х недель, rhLIF - c 8-го дня приема купризона ежедневно в дозе 50 мкг/кг. Методы: гистологический, проточной цитометрии, спектрофотометрический и функциональный. Результаты. Прием купризона вызывает увеличение числа нейронов с деструктивными изменениями в головном и спинном мозге, количества макрофагов, $\mathrm{CD}^{+}$-клеток и содержания малонового диальдегида в головном мозге; наблюдается снижение активности супероксиддисмутазы, глютатионпероксидазы в головном мозге и изменение поведения животных. Инъекции rhLIF частично или полностью восстанавливают измененные купризоном показатели. Эффект цитокина сохраняется через 2 мес после завершения эксперимента. Выводы. Нейропротекторный эффект rhLIF связан с подавлением индуцированных купризоном изменений в активности антиоксидантных ферментов, количестве Т-клеток и макрофагов в головном мозге.

К л юч е в ы е с л о в а: купризон, LIF, нейрон, Т-лимфоциты, макрофаги, антиоксидантные ферменты.

Received 28.05.2018 